\title{
The viability of slim-hole drilling onshore Trinidad
}

\author{
Raffie Hosein ${ }^{1}\left[\right.$. Sheva Serrattan ${ }^{1} \cdot$ Andrew Jupiter ${ }^{1}$
}

Received: 4 March 2017 / Accepted: 31 August 2018 / Published online: 10 September 2018

(c) The Author(s) 2018

\begin{abstract}
Slim-hole drilling refers to the drilling of a well with a wellbore typically less than 7 in. in diameter. Slim-hole drilling is beneficial to the low-budget operator as there are considerable savings on rig time and costs and the rig size is ideal for drilling in remote areas. During slim-hole drilling, drilling fluid hydraulics is of great concern since significant pressure losses can occur in the drill pipe and annulus due to the reduced annular clearances. In addition, the flow regime generated in a slim-hole and the compatibility of the drilling fluid with the formation can have an impact on the stability of the wellbore. Slim-hole drilling has been successfully conducted onshore Trinidad in the Morne Diablo/Quinam Block for a number of years. The most commonly used drilling fluid is saltwater-based mud since it is cheaper and easier to dispose of than oil-based mud. However, the open literature did not show any studies conducted to determine the impact of drilling fluid hydraulics and drilling fluid compatibility on well-bore stability. In this study, 25 water-based drilling mud formulations were prepared using different concentrations of sodium chloride, potassium chloride and calcium chloride. The rheological properties of each formulation were determined and the Bingham plastic and power law models were applied. The frictional pressure losses for three commonly drilled slim-hole configurations were then computed and compared. Outcrop shale samples from the area were then treated with each formulation and the percentage loss in mass due to hydration and disintegration was measured for each sample. The results from these two tests showed that of the mud formulations tested, overall, those with $\mathrm{KCl}(2.9 \%)$ and $\mathrm{CaCl}_{2}(0.7 \%), \mathrm{KCl}(3.6 \%), \mathrm{KCl}(0.7 \%)$ and $\mathrm{NaCl}(2.9 \%), \mathrm{NaCl}(0.7 \%)$, and $\mathrm{CaCl}_{2}(2.9 \%)$ were determined as best suitable for slim-hole drilling for the well configurations used. For these mud formulations, frictional pressure losses using both rheological models were the lowest and provide adequate rheological properties. The outcrop samples also showed the lowest percentage loss by mass when treated with these formulations indicating that they possess the desired well-bore inhibition properties. However, formulations containing $\mathrm{NaCl}$ only are the least expensive with straight $\mathrm{KCl}$ formulations being the most expensive.
\end{abstract}

Keywords Slim-hole $\cdot$ Drilling fluid compatibility $\cdot$ Well bore stability $\cdot$ Trinidad

\section{Introduction}

Drilling operation is one of the highest cost for the oil and gas industry. For a field development, this cost can be in the range of $30-70 \%$ of the capital expenditure (Ross et al. 1992). Slim-hole drilling is one method whereby the cost of drilling a well can be reduced. Slim-hole drilling has been actively used since the 1920 s by the mining industry

Raffie Hosein

raffie.hosein@sta.uwi.edu

1 Petroleum Studies Unit (PSU), Department of Chemical Engineering, The University of the West Indies, St. Augustine, Trinidad and Tobago and was studied in depth in the 1950s for oil and gas field development.

\section{Definition of slim-hole well}

A slim-hole well has been defined in a number of different ways (Shanks and Williams 1993; Finger and Jacobson 2000; Jahn et al. 2008), all of which refer to the drilling of a well with a well-bore typically less than $7 \mathrm{in}$. in diameter. A comparison of hole size and casing programme for a slim-hole well versus a conventional well is shown in Fig. 1 (Shanks and Williams 1993). 


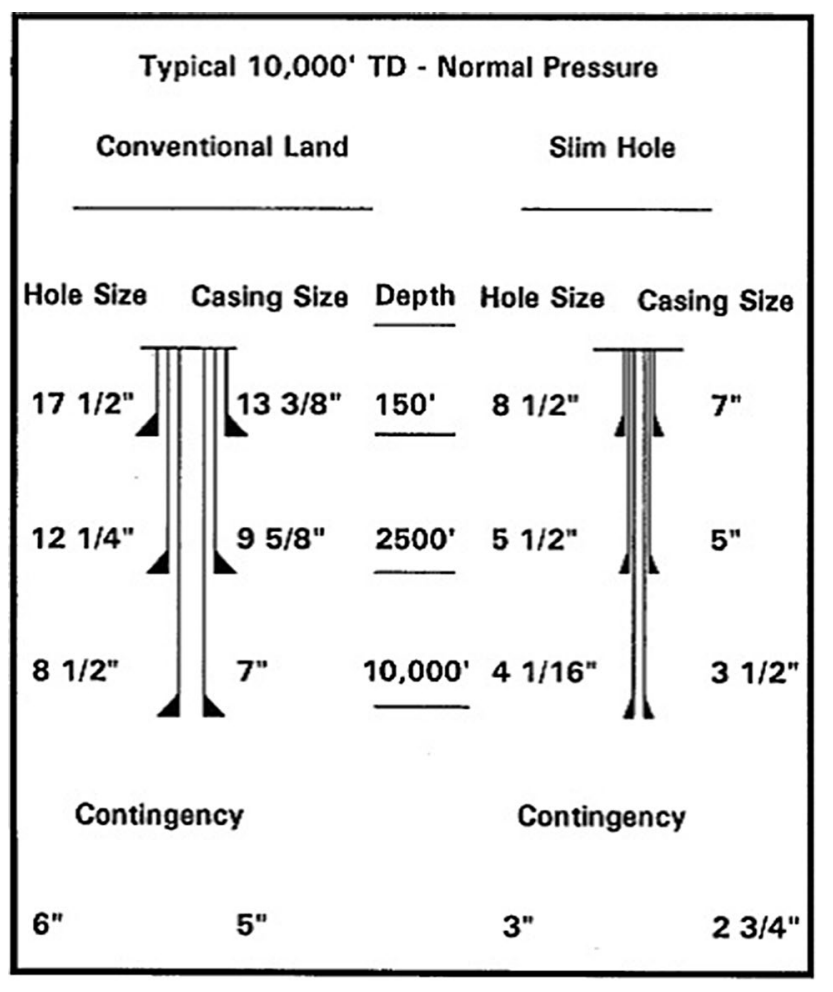

Fig. 1 Typical hole size and casing programme comparison-conventional well versus slim-hole

\section{Benefits of slim-hole drilling}

The cost benefits to be derived from slim-hole drilling can be attributed to the following (Shanks and Williams 1993):

- Smaller rig requirements and reduction in footprint by as much as $75 \%$.

- Reduced rig up times and transportation times.

- Reduced hole diameter by as much as $50 \%$.

- Reduction in consumables such as bits, drilling mud, cement and fuel.

- Reduced cuttings generation by as much as $75 \%$ and lower disposal costs.

- Reduced casing requirements.

- Drilling in remote areas that lack in infrastructure.

\section{Challenges in slim-hole drilling}

\section{Fluid hydraulics}

Zhu and Carroll (1994) explained that the major risk with slim-hole drilling is drill string and tool joint failures. This is because of the smaller and thinner tubular joints which are mechanically weaker than their conventional equivalent. If managed, Delwiche et al. (1992) argue that the major challenges associated with drilling slim-hole wells are fluid hydraulics and drilling fluid compatibility on well-bore stability.

In a conventional well, the pressure loss in the drill pipe typically exceeds that of the annulus. In addition, to optimize bit cleaning, at least $65 \%$ of the total pump pressure should be lost at the bit as indicated by Kendall and Goins (1960). In a slim-hole well, the reduced annular clearances result in these conditions being reversed. The annular pressure loss has been estimated by Bode et al. (1991) to be as high as $90 \%$ of the total fluid circulation pressure loss. Because of this high annular pressure loss, Shanks and Williams (1993) concluded that the models for hydraulic design in conventional wells should be carefully considered for slimhole applications. To minimize annular pressure losses, Zhu and Carroll (1994) propose a shear-thinning viscosity profile-low viscosities while travelling through the bit and up a tight annulus at high velocities and higher viscosities for cutting transport and suspension nearer to surface at lower velocities.

Thonhauser et al. (1995) identified the three major characterizers of well-bore hydraulics to be mud flow rate, mud rheology and well-bore geometry and to some extent drill pipe eccentricity and drill pipe rotation. From an assessment of hydraulic models, they concluded that conventional hydraulic models only provide a rough approximation for slim-hole well-bore hydraulics and that hydraulics models for slim-hole drilling should be used with caution.

\section{Drilling fluid formulation, compatibility and well-bore stability}

Slim-hole geometry and drilling parameters have a great impact on the formulation of drilling fluids. Cartalos and Dupuis (1993) explained that formulations need to be solid free or contain minimal fines. Salts, such as chlorides of sodium, calcium and potassium, can be used as weighting agents, and polymers are preferred as viscosifying agents rather than commercial clays. This is because the lower solid content translates into a lower internal friction.

Zhu and Carroll (1994) explained that annular pressure losses become increasingly important in slim-holes especially where there is a narrow range between pore pressure and formation fracture pressure. They further discussed that, to minimize annular pressure losses, a shear-thinning viscosity profile is desirable-low viscosities while travelling through the bit and up a tight annulus at high velocities and higher viscosities for cutting transport and suspension nearer to surface at lower velocities. Cutting transport in general is affected because the rheological properties, including gel strengths, must be kept low, thereby reducing the ability of the fluid to suspend cuttings under static conditions. 
It is also important to examine a drilling fluid not only for its rheological control but also to independently examine its efficacy in preventing hydration of consolidated shales. Lal (1999) indicated that over $75 \%$ of the drilled sedimentary type formations are comprised of shale and over $70 \%$ of the borehole problems are linked to shale instability. Shale instability problems are often caused by incompatibilities between drilling fluid and shale formations which can result in washouts, low rates of penetration, higher drilling costs and shale sloughing. Friedheim et al. (2011) suggested that shale samples for testing can be derived from field-specific, troublesome formations, outcrop samples with similar mineralogy, or synthetic shale; properly preserved shale cores would be ideal and provide the most accurate results. Cores, however, are indicated to be difficult and expensive to obtain but a good substitute may be cavings or cuttings from a drilled well, that are large enough and with minimal drilling fluid exposure. Laboratory studies such as clay hydration and swelling tests are conducted; however, fluid-shale interaction is complex and sometimes not well understood.

\section{Rheological models and hydraulics}

Drilling fluids can be defined by an appropriate rheological model. The rheological model is then applied to fluid friction correlations to determine pressure losses throughout the entire circulating system. Pressure losses are optimized to ensure that the drilling fluid accurately carries out its functions of penetration, hole cleaning, hole stability and pressure control. Rheological models and fluid friction correlations are, therefore, essential tools that are needed for developing a hydraulics programme for slim-holes.

Rheology is measured using a viscometer and values of shear stress and shear rates are obtained. The relationship between shear stress $(\tau)$ and shear rate $(\gamma)$ is used to determine the rheological model which best describes the fluid flow behaviour. Shear stress is measured as force per unit area and shear rate is defined as the absolute velocity gradient. Viscosity is the resistance offered by a fluid to deformation when subjected to a shear stress.

The relationship between flow pressure and flow rate determines the flow characteristics of a fluid. There are two fundamental relationships:

1. Laminar flow which exists at low flow velocities where flow is orderly and the pressure velocity relationship is a function of the viscosity of the fluid.

2. Turbulent flow which exists at higher flow velocities where flow is disorderly and is a function of the inertial properties of the fluid in motion.
Laminar flow for slim-hole drilling hydraulics is preferred. There are five flow equations relating flow behaviour to flow characteristics. However, drilling fluids do not conform strictly to any one model but fluid behaviour can be predicted with sufficient accuracy by one or more of them. The five flow models are as follows.

\section{Newtonian}

A Newtonian fluid (Newton 1687) is one where the viscosity is independent of shear rate, i.e. the shear stress is related linearly to the shear rate. It is described mathematically below:

$\tau=\mu \gamma$,

where $\mu$ is the constant equating to the viscosity of the fluid.

\section{Bingham plastic}

A Bingham plastic fluid (Bingham 1922) is one which requires a finite shear stress, $\tau_{y}$, or yield point, to initiate flow. Above this yield point, the shear rate is linear with the shear stress but below the yield point, the fluid behaves as a solid. It is described mathematically below:

$\tau=\tau_{\mathrm{y}}+\mu_{\mathrm{p}} \gamma$,

where $\mu_{\mathrm{p}}$ is the constant equating to the plastic viscosity

Most drilling fluids exhibit Binghamian behaviour and can be characterized by PV and YP values although this may not be the best model to describe the fluid.

\section{Pseudoplastic (Ostwaldian or Power Law)}

A pseudoplastic fluid (Ostwald 1929) exhibits a linear relationship between shear stress and shear rate when plotted on $\log -\log$ paper. It is described mathematically below:

$\tau=K \gamma^{n} \quad$ and $\quad n<1$,

where $K$ is the consistency index and $n$ is the power law index

Pseudoplastic fluids are also referred to as shear thinning, i.e. viscosity decreases as shear rate increases. Some drilling fluids, such as polymeric solutions, exhibit pseudoplastic behaviour.

\section{Yield power law (Herschel-Bulkley)}

A yield power law (Herschel and Bulkley 1926) fluid is one which requires a finite shear stress or yield point, below which it will not flow. Above this yield point, the shear stress varies with shear rate according to the pseudoplastic model. It is described mathematically below:

$$
\tau=\tau_{\mathrm{y}}+K \gamma^{m},
$$


where $\tau_{\mathrm{y}}$ is the yield point, $K$ is the consistency index, and $M$ is the power law index.

\section{Dilatant}

Dilatant fluids exhibit a linear relationship between shear stress and shear rate when plotted on log-log paper; however, as shear rate increases, shear stress increases. Dilatant fluids are also known as shear-thickening fluids. It is described mathematically below:

$t=K \gamma^{n} \quad$ and $\quad n>1$.

\section{Hydraulics}

\section{Fluid friction}

For pipe flow, the frictional pressure drop can generally be described as follows:

$\Delta P=\left\{\left(2 f \rho v^{2}\right) / D_{i}\right\} \Delta z$,

where $\Delta P$ is the frictional pressure drop, $f$ Fanning friction factor, $\rho$ density of the fluid, $D_{i}$ characteristic diameter, $v$ velocity of the fluid, and $\Delta z$ length

This is modified slightly for flow in the annulus:

$$
\Delta P=\left\{\left(2 f \rho v^{2}\right) / D_{\mathrm{o}}-D_{\mathrm{i}}\right\} \Delta z
$$

where $D_{\mathrm{o}}$ is the outer diameter and $D_{\mathrm{i}}$ internal diameter

The Fanning friction factor (Fanning 1877) is a dimensionless number that depends on fluid density, fluid velocity, fluid viscosity, fluid type and pipe roughness. The relationships between the Fanning friction factor and another dimensionless number, the Reynolds number, Re, (Reynolds 1883) have been developed from experimental data. Correlations for the Fanning friction factor and Reynolds number are available for laminar and turbulent flow regimes, and for different fluid types and geometries.
The Reynolds number, $R e$, can be generally described as follows:

$R e=D \rho v / \mu$,

where $D$ is the characteristic length (pip diameter), $\rho$ density of the fluid, $v$ average velocity, and $\mu$ characteristic viscosity.

The critical Reynolds number, $R e_{\mathrm{c}}$, (Reynolds 1883) typically describes the point at which flow transitions from laminar to turbulent. For example, for flow in a pipe, laminar flow occurs when $R e_{\mathrm{c}}<2300$ and turbulent flow occurs when $R e_{\mathrm{c}}>4000$. Between 2300 and 4000 both laminar and turbulent flows are possible and this can be described as transition flow.

\section{Slim-hole drilling in the Morne Diablo/ Quinam Block}

The Morne Diablo/Quinam Block is located in southern Trinidad as shown in Fig. 2 (Energy-pedia News 2012). It has been developed over the past 16 years by drilling and completing slim-hole wells, typically 6-6 7/8 in. hole with $4 \frac{1}{2}-5 \frac{1}{2}$ in. production casing. Drilled depths range from about 300 to $3000 \mathrm{ft}$. The benefits were savings in costs due to reductions in manpower, location size, casing and drilling tubular size, mud volumes, cementing volumes and fuel which made exploitation of these shallow and marginal reserves economic.

Wach and Archie (2008) state that the oil-bearing stratigraphic sequence consists of the Forest and Cruse Formations of Pliocene age. The lithological framework of these oil reservoirs consists of sand with varying degrees of silt and dispersed clays. According to Ramkhalawan et al. (1995), the reservoirs themselves are poorly consolidated (often with exceptionally high porosities $>20 \%$, high water saturation $>25 \%$ and produce sand) and contain inter-bedded shale laminations.

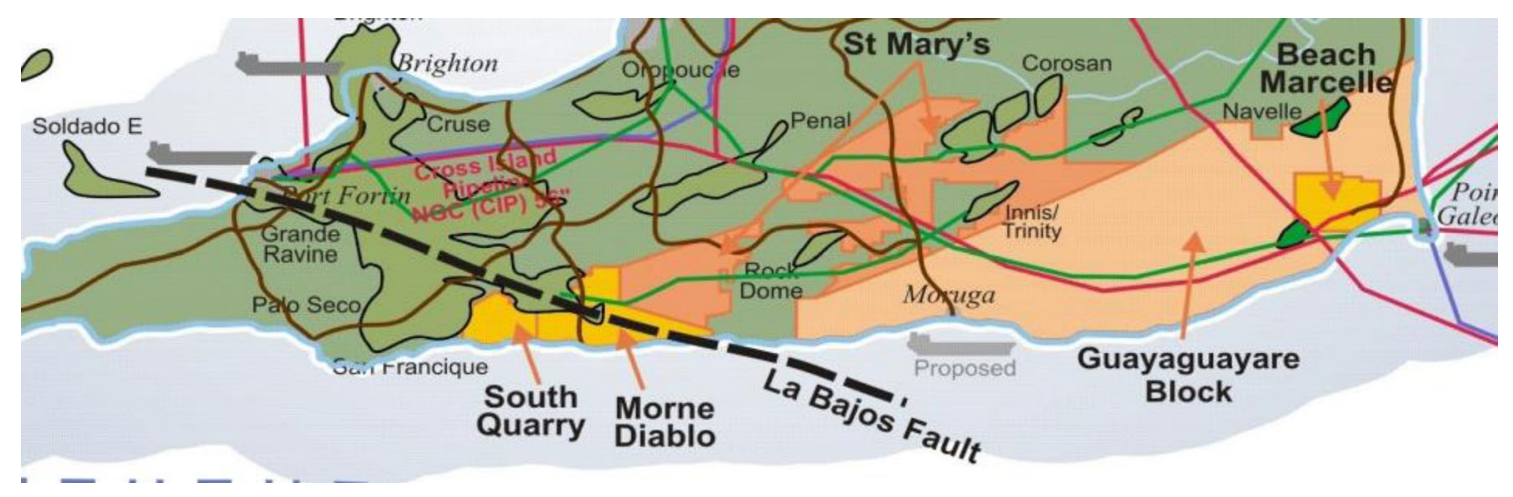

Fig. 2 Map showing location of Morne Diablo Block in southern Trinidad

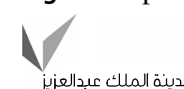

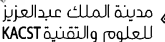
Springer 
During the drilling of these slim-hole wells, well-bore instability and erratic mud rheological properties were observed. The main challenges thus experienced were wellbore cavings, stuck pipe, improper hole cleaning, ballooning, fracturing, shale sloughing and hole enlargement. It is suspected that these problems stem from the highly reactive nature of immature clays present in the area as well as mud compatibility.

\section{Objectives of study}

The typical drilling fluid systems, used to drill slim-holes in the Morne Diablo/Quinam Block, are salt water systems, mainly sodium chloride and potassium chloride. This study was conducted to determine the rheological properties of the commonly used mud formulations containing these salts and the frictional pressure losses for three commonly drilled slim-hole configurations. Outcrop shale samples from the area were treated with each formulation to determine fluid compatibility. The objective was to recommend suitable drilling mud formulations for future slim-hole drilling operations in onshore Trinidad. Cores samples were not available for this study. However, previous studies (Wach and Archie 2008) show that the outcrop samples selected for this study were representative of the Cruse Formation with similar mineral composition.

\section{Methodology}

\section{Drilling mud rheology}

The drilling fluids were prepared and tested based on the methodology outlined by Enilari (2005) for the development and evaluation of various drilling fluids for slim-hole wells. However, for this study, because weighted muds were required, high-concentration brines would not be cost effective. Instead, barite-weighted mud systems were prepared with different salinities and tested.

The compositions of 25 water-based drilling fluid samples were prepared using varying combinations of sodium chloride, potassium chloride and calcium chloride as shown in Table 1 . The samples were allowed to hydrate for $12 \mathrm{~h}$. No salts were added to the first formulation which was used as the control. The rheologies of each formulation were determined at approximate well temperature of $120 \pm 5^{\circ} \mathrm{F}$ using a typical six-speed Fann viscometer as shown in Fig. 3. The rheologies were used to determine the best fit rheological model (Bingham plastic or power law) using the equations in Table 2 and shear stress-shear rate plots as shown in Fig. 4.

The rheological model was then used to determine the annular frictional pressure loss gradients for three commonly drilled slim-hole configurations, tubulars and pump rates outlined below:

1. 4.5 in. drill pipe (3.286 in. ID) in 6 in. hole;

2. 3.5 in. drill pipe (2.602 in. ID) in 6 in. hole;

3. $23 / 8$ in. drill pipe (1.995 in. ID) in 4 in. hole.

Flow rate ranges were chosen to include an annular velocity of $150 \mathrm{ft} / \mathrm{min}$ and the pressure losses were calculated using three flow rates as follows:

- For configurations 1 and 2: $100 \mathrm{gpm}, 150 \mathrm{gpm}$ and 200 gpm.

- For configuration 3: $50 \mathrm{gpm}, 100 \mathrm{gpm}$ and $150 \mathrm{gpm}$.

\section{Experimental studies on drilling fluid compatibility}

Equivalent salt solutions were prepared to represent each drilling fluid formulation. Shale samples taken from an outcrop were cut into 1-in. cubes and weighed to approximately $30 \mathrm{~g}$. Each shale sample was then exposed to each formulation for $2 \mathrm{~h}$, then gently rinsed to remove any surface-hydrated clay and then dried at $140 \pm 5^{\circ} \mathrm{F}$ for $2 \mathrm{~h}$. The difference in mass before and after exposure to the mud formulations was determined.

Drilling fluid samples were then prepared for the nine formulations that produced the least difference, as well as the control formulation. $50 \mathrm{~g}$ of clay particles, roughly $3 / 4 \mathrm{in}$. in size, was then exposed to each of the ten selected formulations in duplicate. The samples were then lightly rinsed and dried for $6 \mathrm{~h}$ at $140 \pm 5^{\circ} \mathrm{F}$ for $6 \mathrm{~h}$. Again, the differences in mass before and after exposure were determined.

\section{Results and discussion}

\section{Rheology models}

The rheological data in Appendix A1 was used to construct shear stress versus shear rate plots. An example is shown in Fig. 4 for formulation DF1. The correlation coefficients were calculated for each formulation for both Bingham plastic and power law models. The intention was to select the model which best fits the data. However, all calculated correlation values were above 0.975 and it can be argued that any of the formulations can conform to either rheological model. Therefore, it was decided that the pressure losses would be calculated for both models and the results were compared. 
Table 1 Drilling fluid formulations

\begin{tabular}{|c|c|c|c|c|c|c|c|c|c|c|c|}
\hline \multirow[t]{2}{*}{ Formulation \# } & \multicolumn{8}{|c|}{ Mass of components (g) } & \multicolumn{3}{|c|}{$\begin{array}{l}\text { Concentration (by } \\
\text { weight) }\end{array}$} \\
\hline & Water & Bentonite & Xanthan gum & PAC & $\mathrm{KCl}$ & $\mathrm{NaCl}$ & $\mathrm{CaCl}_{2}$ & Barite & $\mathrm{KCl}$ & $\mathrm{NaCl}$ & $\mathrm{CaCl}_{2}$ \\
\hline DF0 & 350 & 5 & 0.5 & 2 & 0.0 & 0.0 & 0.0 & 384 & 0.0 & 0.0 & 0.0 \\
\hline DF1 & 350 & 5 & 0.5 & 2 & 3.5 & 0.0 & 0.0 & 384 & 0.7 & 0.0 & 0.0 \\
\hline DF2 & 350 & 5 & 0.5 & 2 & 7.0 & 0.0 & 0.0 & 384 & 1.4 & 0.0 & 0.0 \\
\hline DF3 & 350 & 5 & 0.5 & 2 & 10.5 & 0.0 & 0.0 & 384 & 2.2 & 0.0 & 0.0 \\
\hline DF4 & 350 & 5 & 0.5 & 2 & 14.0 & 0.0 & 0.0 & 384 & 2.9 & 0.0 & 0.0 \\
\hline DF5 & 350 & 5 & 0.5 & 2 & 17.5 & 0.0 & 0.0 & 384 & 3.6 & 0.0 & 0.0 \\
\hline DF6 & 350 & 5 & 0.5 & 2 & 0.0 & 3.5 & 0.0 & 384 & 0.0 & 0.7 & 0.0 \\
\hline DF7 & 350 & 5 & 0.5 & 2 & 0.0 & 7.0 & 0.0 & 384 & 0.0 & 1.4 & 0.0 \\
\hline DF8 & 350 & 5 & 0.5 & 2 & 0.0 & 10.5 & 0.0 & 384 & 0.0 & 2.2 & 0.0 \\
\hline DF9 & 350 & 5 & 0.5 & 2 & 0.0 & 14.0 & 0.0 & 384 & 0.0 & 2.9 & 0.0 \\
\hline DF10 & 350 & 5 & 0.5 & 2 & 0.0 & 17.5 & 0.0 & 384 & 0.0 & 3.6 & 0.0 \\
\hline DF11 & 350 & 5 & 0.5 & 2 & 0.0 & 0.0 & 3.5 & 384 & 0.0 & 0.0 & 0.7 \\
\hline DF12 & 350 & 5 & 0.5 & 2 & 0.0 & 0.0 & 7.0 & 384 & 0.0 & 0.0 & 1.4 \\
\hline DF13 & 350 & 5 & 0.5 & 2 & 0.0 & 0.0 & 10.5 & 384 & 0.0 & 0.0 & 2.2 \\
\hline DF14 & 350 & 5 & 0.5 & 2 & 0.0 & 0.0 & 14.0 & 384 & 0.0 & 0.0 & 2.9 \\
\hline DF15 & 350 & 5 & 0.5 & 2 & 0.0 & 0.0 & 17.5 & 384 & 0.0 & 0.0 & 3.6 \\
\hline DF16 & 350 & 5 & 0.5 & 2 & 14.0 & 3.5 & 0.0 & 384 & 2.9 & 0.7 & 0.0 \\
\hline DF17 & 350 & 5 & 0.5 & 2 & 8.8 & 8.8 & 0.0 & 384 & 1.8 & 1.8 & 0.0 \\
\hline DF18 & 350 & 5 & 0.5 & 2 & 3.5 & 14.0 & 0.0 & 384 & 0.7 & 2.9 & 0.0 \\
\hline DF19 & 350 & 5 & 0.5 & 2 & 14.0 & 0.0 & 3.5 & 384 & 2.9 & 0.0 & 0.7 \\
\hline DF20 & 350 & 5 & 0.5 & 2 & 8.8 & 0.0 & 8.8 & 384 & 1.8 & 0.0 & 1.8 \\
\hline DF21 & 350 & 5 & 0.5 & 2 & 3.5 & 0.0 & 14.0 & 384 & 0.7 & 0.0 & 2.9 \\
\hline DF22 & 350 & 5 & 0.5 & 2 & 0.0 & 14.0 & 3.5 & 384 & 0.0 & 2.9 & 0.7 \\
\hline DF23 & 350 & 5 & 0.5 & 2 & 0.0 & 8.8 & 8.8 & 384 & 0.0 & 1.8 & 1.8 \\
\hline DF24 & 350 & 5 & 0.5 & 2 & 0.0 & 3.5 & 14.0 & 384 & 0.0 & 0.7 & 2.9 \\
\hline
\end{tabular}

Table 2 Equations for determination of rheological properties for Bingham plastic and power law models

\begin{tabular}{llll}
\hline Rheological model & Property & Equation & Units \\
\hline Bingham plastic & Plastic viscosity $\left(\mathrm{PV}\right.$ or $\left.\mu_{\mathrm{p}}\right)$ & $\mu_{\mathrm{p}}=\theta_{600}-\theta_{300}$ (Eq. 9) & $\mathrm{cP}$ \\
Bingham plastic & Yield point (YP or $\left.\tau_{0}\right)$ & $\tau_{0}=\theta_{300}-\mu_{\mathrm{p}}$ (Eq. 10) & $\mathrm{lbf} / 100 \mathrm{ft}^{2}$ \\
Power law & Flow behaviour index $(n)$ & $n=\frac{\ln \left(\frac{\tau_{600}}{\tau_{300}}\right)}{\ln \left(\frac{600}{300}\right)}$ (Eq. 11) & Dimensionless \\
& & $K=\frac{\tau_{300}}{510.9^{n}}$ (Eq. 12) & $\mathrm{Pa} \mathrm{s}$ \\
Power law & Consistency index $(K)$ & & \\
\hline
\end{tabular}

\section{Annular frictional pressure losses}

The calculated rheological properties for each mud formulation were used in the determination of the frictional pressure losses in the drill pipe and annulus for the configurations and flow rates indicated in Appendix A2.

The summarized results comparing APL gradients (for approximately $150 \mathrm{ft} / \mathrm{min}$ annular velocity) are shown in Table 3. The following are general observations made after assessment of the results: 


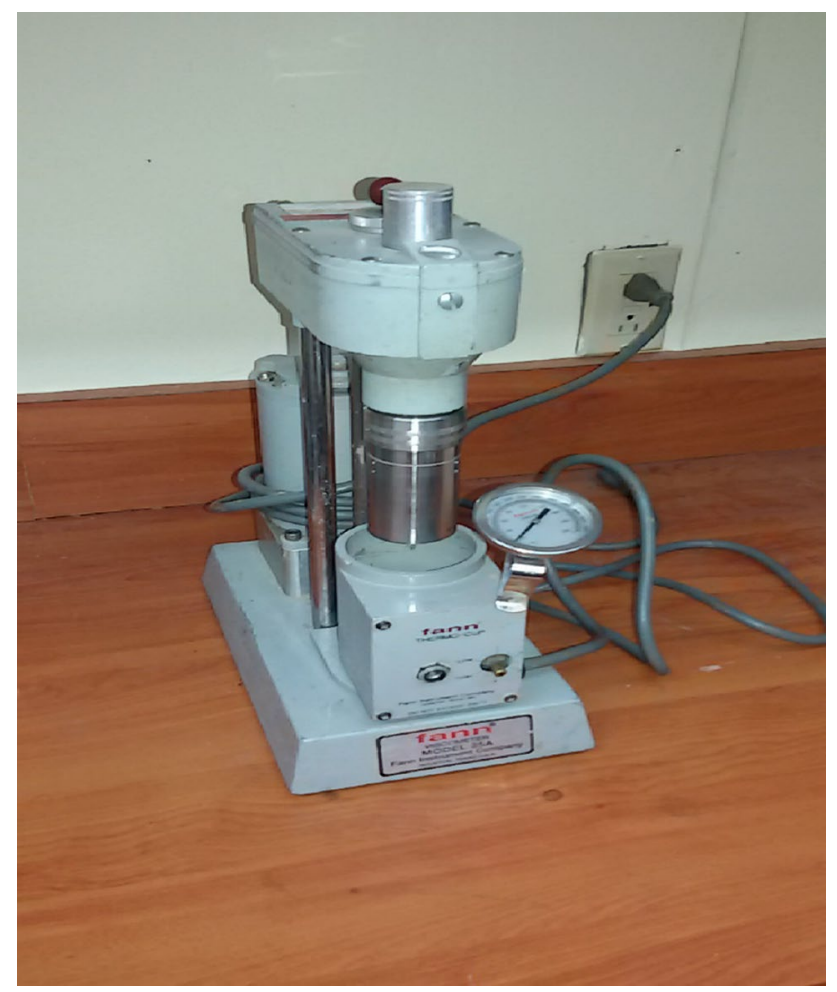

Fig. 3 Typical Fann Model 35 Viscometer

- There were significant differences between values generated using the Bingham plastic model and those generated using the power law model.
- For laminar flow, the power law model produced lower pressure losses when compared to the Bingham plastic model.

- For turbulent flow, the Bingham plastic model produced lower pressure losses when compared to the power law model.

- Exceptionally high APL gradients (over 1 psi/ft) were generated for configurations 1 and 3 using the power law model. This was due to the small annular clearance and is typical with higher flow rates (200 gpm for configuration 1 and $150 \mathrm{gpm}$ for configuration 2).

- The Bingham plastic model generated some high pressure loss gradients but none were exceptionally high (over $1 \mathrm{psi} / \mathrm{ft}$ ).

- There were significant differences in APLs from laminar to transitional to turbulent using the power law model. Therefore, modifications were made to the APL charts, removing the turbulent sections so that the remaining data would be properly displayed. This is shown in Appendix A3.

- The formulations with the least frictional losses are ranked and shown in Table 4.

\section{Inhibition study}

The following observations regarding the inhibition study were noted (results shown in Figs. 5, 6):
Fig. 4 Rheological plot for DF1 showing best fit curves and correlation coefficients

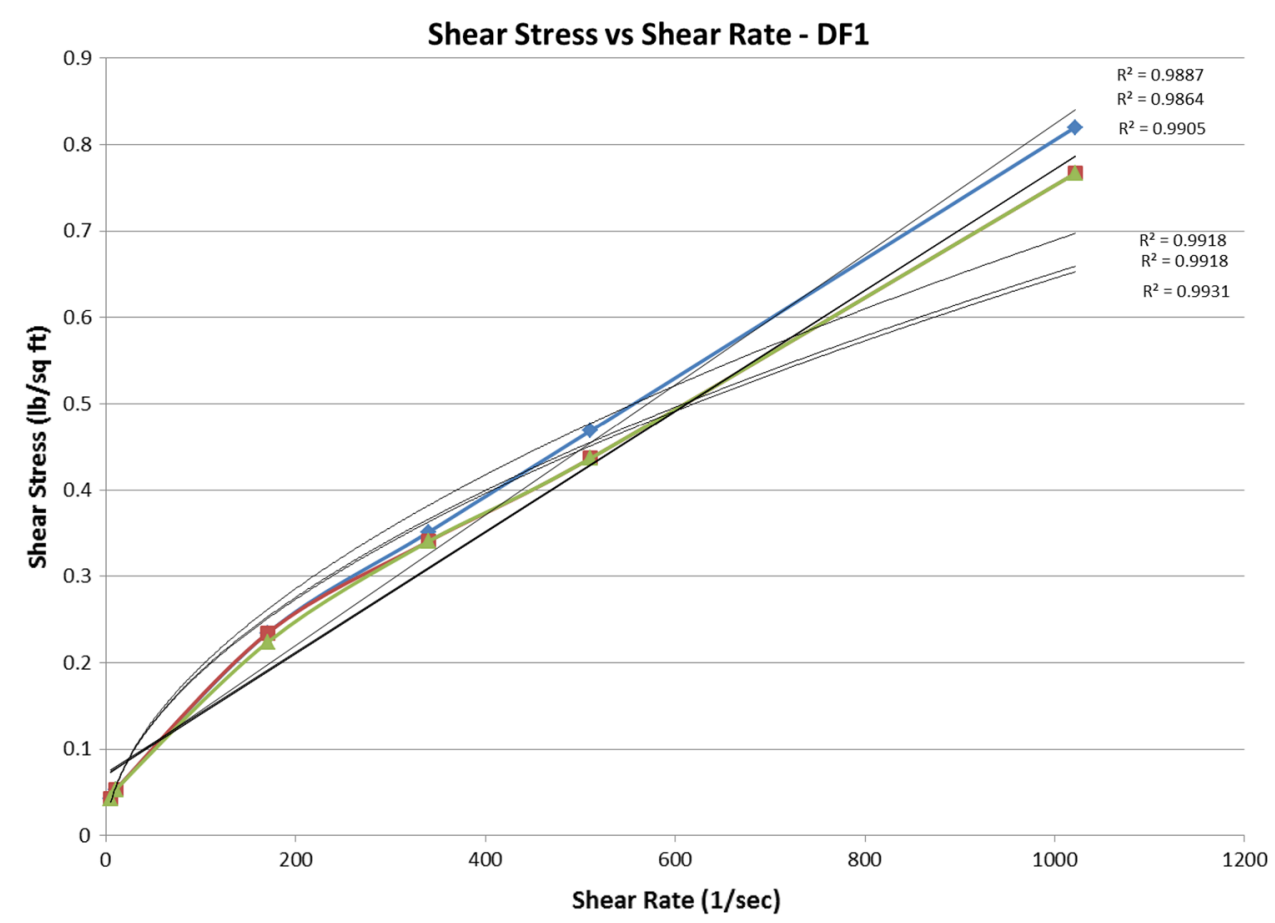

Shear Rate (1/sec) 
Table 3 Comparison of APL gradients for Bingham plastic and power law models
Table 4 Drilling fluid formulations ranked by frictional performance for both rheological models and all three configurations

\begin{tabular}{|c|c|c|c|c|c|c|}
\hline \multirow{2}{*}{$\begin{array}{l}\text { Configuration } \\
\text { Rheology model }\end{array}$} & \multicolumn{2}{|l|}{3} & \multicolumn{2}{|l|}{1} & \multicolumn{2}{|l|}{2} \\
\hline & $\mathrm{BP}$ & PL & $\mathrm{BP}$ & PL & $\mathrm{BP}$ & PL \\
\hline Flow rate (gpm) & $50 \mathrm{gpm}$ & $50 \mathrm{gpm}$ & $100 \mathrm{gpm}$ & $100 \mathrm{gpm}$ & $150 \mathrm{gpm}$ & $150 \mathrm{gpm}$ \\
\hline Formulation \# & \multicolumn{6}{|c|}{ Annular pressure loss gradients (psi/ft) } \\
\hline DF0 & 0.224 & 0.046 & 0.249 & 0.074 & 0.270 & 0.099 \\
\hline DF1 & 0.114 & 0.028 & 0.133 & 0.049 & 0.151 & 3.145 \\
\hline DF2 & 0.083 & 0.022 & 0.100 & 0.040 & 0.115 & 3.137 \\
\hline DF3 & 0.091 & 0.022 & 0.106 & 0.039 & 0.120 & 3.090 \\
\hline DF4 & 0.091 & 0.022 & 0.107 & 0.040 & 0.122 & 3.102 \\
\hline DF5 & 0.082 & 0.021 & 0.097 & 0.038 & 0.112 & 3.115 \\
\hline DF6 & 0.083 & 0.022 & 0.098 & 0.039 & 0.113 & 3.126 \\
\hline DF7 & 0.130 & 0.029 & 0.149 & 0.050 & 0.166 & 3.091 \\
\hline DF8 & 0.083 & 0.022 & 0.098 & 0.039 & 0.113 & 3.126 \\
\hline DF9 & 0.074 & 0.021 & 0.090 & 0.038 & 0.105 & 3.149 \\
\hline DF10 & 0.094 & 0.024 & 0.112 & 0.044 & 0.128 & 3.146 \\
\hline DF11 & 0.070 & 0.018 & 0.083 & 1.413 & 0.095 & 3.079 \\
\hline DF12 & 0.098 & 0.022 & 0.112 & 0.038 & 0.125 & 3.035 \\
\hline DF13 & 0.099 & 0.023 & 0.114 & 0.040 & 0.128 & 3.063 \\
\hline DF14 & 0.089 & 0.021 & 0.104 & 0.037 & 0.117 & 3.063 \\
\hline DF15 & 0.218 & 0.043 & 0.239 & 0.068 & 0.257 & 0.088 \\
\hline DF16 & 0.084 & 0.023 & 0.101 & 0.041 & 0.116 & 3.147 \\
\hline DF17 & 0.102 & 0.025 & 0.119 & 0.044 & 0.135 & 3.113 \\
\hline DF18 & 0.074 & 0.021 & 0.091 & 0.039 & 0.106 & 3.159 \\
\hline DF19 & 0.043 & 0.016 & 0.057 & 1.446 & 0.096 & 3.159 \\
\hline DF20 & 0.061 & 0.017 & 0.073 & 1.419 & 0.085 & 3.095 \\
\hline DF21 & 0.210 & 0.042 & 0.231 & 0.067 & 0.250 & 0.088 \\
\hline DF22 & 0.073 & 0.020 & 0.089 & 0.037 & 0.103 & 3.139 \\
\hline DF23 & 0.042 & 0.015 & 0.054 & 1.436 & 0.093 & 3.139 \\
\hline DF24 & 0.154 & 0.032 & 0.172 & 0.052 & 0.188 & 3.005 \\
\hline
\end{tabular}

\begin{tabular}{|c|c|c|c|c|c|c|}
\hline & \multicolumn{6}{|c|}{ Configuration } \\
\hline & \multicolumn{3}{|c|}{ Bingham plastic } & \multicolumn{3}{|c|}{ Power law } \\
\hline & 1 & 2 & 3 & 1 & 2 & 3 \\
\hline 1 & DF23 & DF23 & DF23 & DF23 & DF23 & DF23 \\
\hline 2 & DF19 & DF19 & DF19 & DF19 & DF19 & DF19 \\
\hline 3 & DF20 & DF20 & DF20 & DF20 & DF20 & DF20 \\
\hline 4 & DF11 & DF11 & DF11 & DF11 & DF11 & DF11 \\
\hline 5 & DF22 & DF22 & DF22 & DF22 & DF22 & $\mathrm{DF} 22$ \\
\hline 6 & DF9 & DF9 & DF9 & DF14 & DF9 & DF9 \\
\hline 7 & DF18 & DF18 & DF18 & DF9 & DF18 & DF14 \\
\hline 8 & DF5 & DF5 & DF5 & DF5 & DF5 & DF5 \\
\hline 9 & DF6 & DF6 & DF6 & DF12 & DF14 & DF18 \\
\hline 10 & DF8 & DF8 & DF8 & DF18 & DF6 & DF6 \\
\hline
\end{tabular}




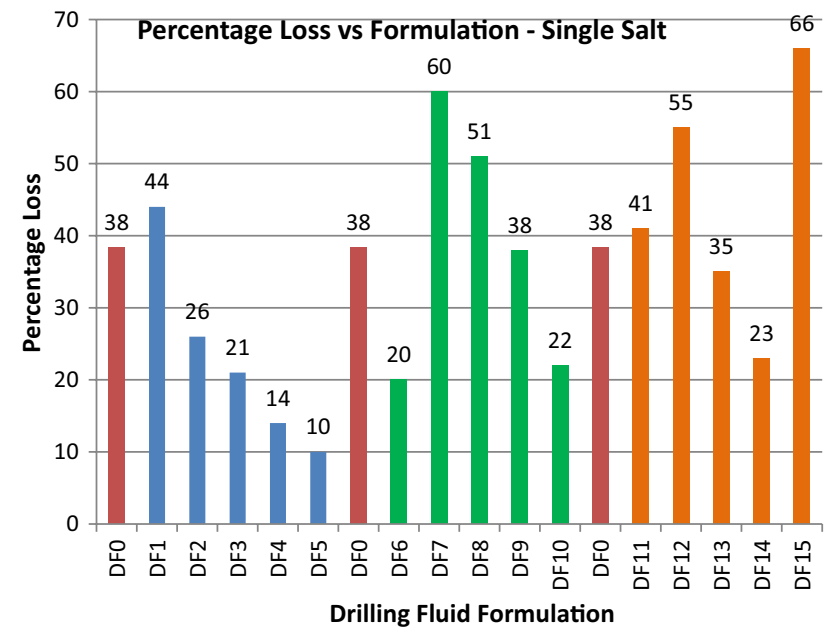

Fig. 5 Percentage shale sample loss versus drilling fluid formulation-single-salt solutions

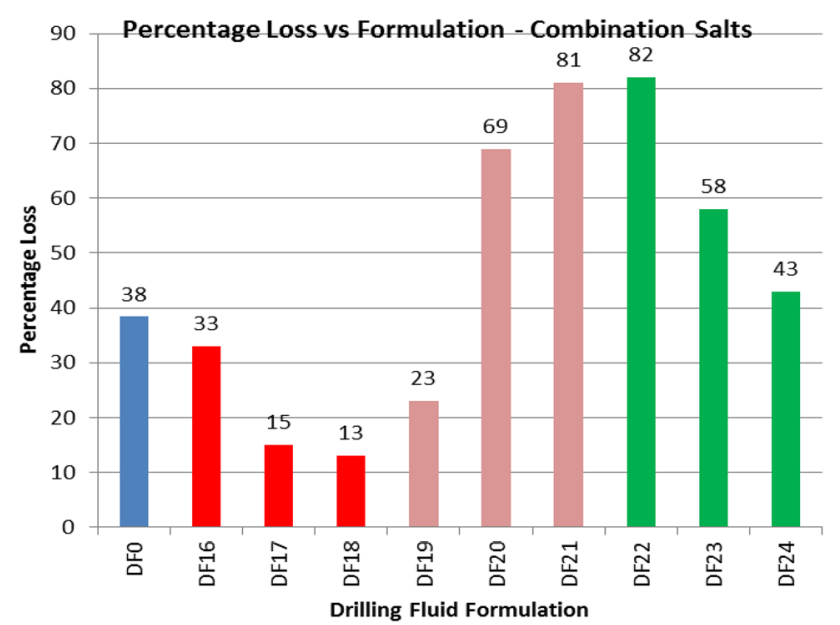

Fig. 6 Percentage shale sample loss versus drilling fluid formulation-combination-salt solutions

- The best performing solutions appeared to be those with $\mathrm{KCl}$. The single-salt solutions of $\mathrm{KCl}$ showed a continuous decrease in percentage loss, i.e. an increase in shale stabilization with increasing salt concentration from 44 to $10 \%$, DF1 ( $0.72 \%$ by weight) to DF5 (3.6\% by weight). There was also a similar relationship with the $\mathrm{KCl}$ and $\mathrm{NaCl}$ combination-salt solutions from DF16 to DF18 from 33 to $13 \%$.

- The single-salt $\mathrm{NaCl}$ solutions showed a similar trend to the $\mathrm{KCl}$ solutions. However, it appeared to be not as effective ranging from 60 to $22 \%$ from DF7 to DF10. DF6 was the exception as it generated only a $20 \%$ loss and does not fit into the general trend.
- The single-salt $\mathrm{CaCl}_{2}$ solutions appeared to show no trend and were also less effective than the $\mathrm{KCl}$ solutions. The worst solution was DF15 (3.6\% $\mathrm{CaCl}_{2}$ by weight) and the best was DF14 (2.9\% $\mathrm{CaCl}_{2}$ by weight).

- The combination of $\mathrm{KCl}$ and $\mathrm{CaCl}_{2}$ exhibited increasing percentage loss with increasing $\mathrm{CaCl}_{2}$ concentration and decreasing $\mathrm{KCl}$ concentration but did not perform as well as $\mathrm{KCl}-\mathrm{NaCl}$ combinations.

The combination of $\mathrm{NaCl}$ and $\mathrm{CaCl}_{2}$ exhibited decreasing percentage loss with increasing $\mathrm{CaCl}_{2}$ concentration and decreasing $\mathrm{NaCl}$ concentration but does not perform as well as $\mathrm{KCl}-\mathrm{NaCl}$ combinations.

- When the tests were conducted using the actual drilling fluids, no discernible trends were observed. However, the most inhibitive fluids contained some amount of potassium chloride. These results are shown in Fig. 7.

\section{Economics}

Table 5 shows the cost per barrel for each formulation. It shows that the least expensive salt-containing formulation is $3.5 \mathrm{ppb}$ sodium chloride at USD 10.85. The most expensive formulation is the $17.5 \mathrm{ppb}$ potassium chloride at USD 22.05 which is more than double in cost compared to the former. Generally, the least expensive salt is sodium chloride followed by calcium chloride with potassium chloride being the most expensive. This is illustrated in Table 5 as it shows that typically, the formulations with higher concentrations of potassium chloride are the most expensive while those containing more sodium chloride are the least expensive. Intuitively, the higher concentration of any salt reflects a higher cost.

\section{Conclusions}

The objective of the study was to formulate different saltwater-based drilling fluids using different salts and to assess the efficacy of each formulation with respect to the annular and drill pipe frictional pressure losses generated. A second objective was to assess the ability of the formulation to aid in stabilizing the well-bore with respect to shale.

The following conclusions were made:

1. Drilling fluids containing $\mathrm{CaCl}_{2}$, generally, produced the lowest fictional pressure losses when compared to the other salts, in particular in combination with another salt and in a low concentration.

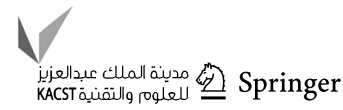


Fig. 7 Average percentage loss-drilling fluid formation stability test

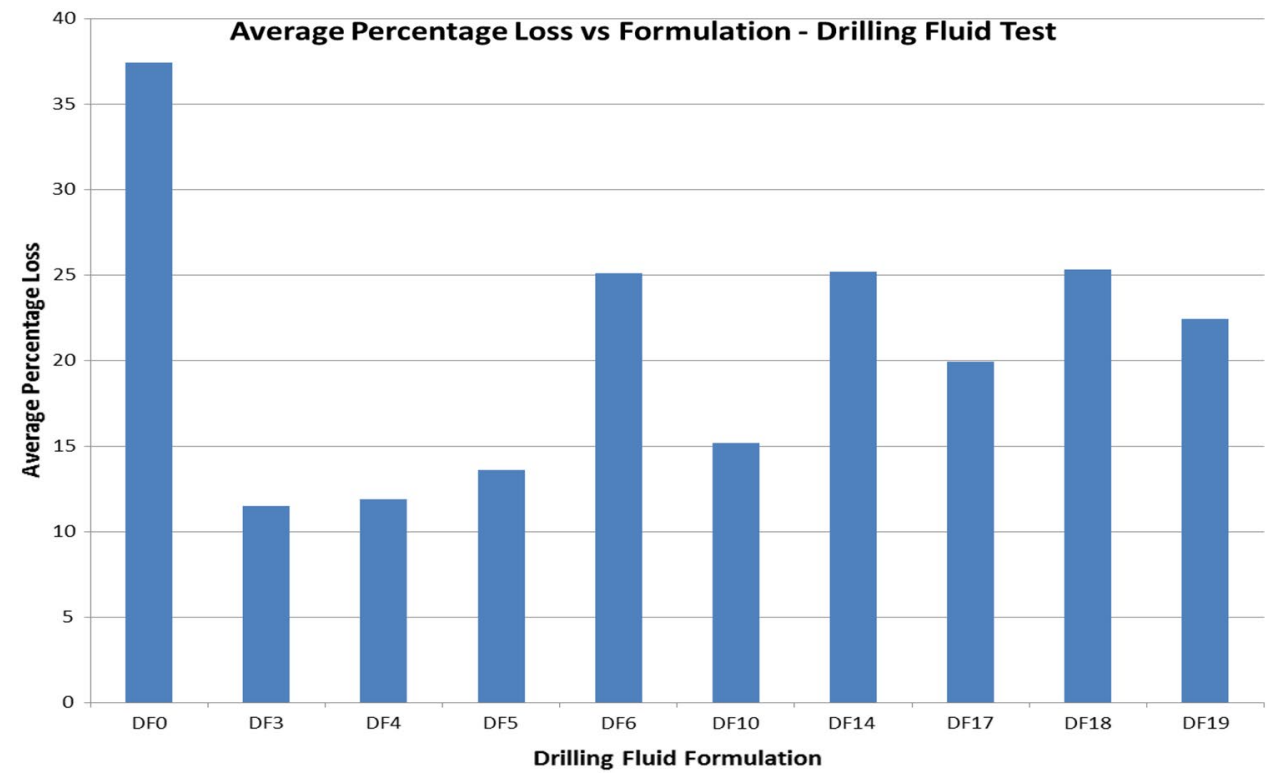

Table 5 Drilling fluid formulations ranked by cost per barrel

\begin{tabular}{|c|c|c|c|c|}
\hline \multirow{2}{*}{$\begin{array}{l}\text { Formula- } \\
\text { tion \# }\end{array}$} & \multicolumn{3}{|c|}{ Concentration } & \multirow{2}{*}{$\begin{array}{l}\text { Cost } \\
\text { USD (per bbl) }\end{array}$} \\
\hline & $\mathrm{KCl}(\mathrm{ppb})$ & $\mathrm{NaCl}(\mathrm{ppb})$ & $\mathrm{CaCl}_{2}(\mathrm{ppb})$ & \\
\hline DF0 & 0 & 0 & 0 & 10.42 \\
\hline DF6 & 0 & 3.5 & 0 & 10.85 \\
\hline DF11 & 0 & 0 & 3.5 & 11.25 \\
\hline DF7 & 0 & 7 & 0 & 11.28 \\
\hline DF8 & 0 & 10.5 & 0 & 11.71 \\
\hline DF12 & 0 & 0 & 7 & 12.08 \\
\hline DF9 & 0 & 14 & 0 & 12.15 \\
\hline DF10 & 0 & 17.5 & 0 & 12.58 \\
\hline DF1 & 3.5 & 0 & 0 & 12.74 \\
\hline DF13 & 0 & 0 & 10.5 & 12.91 \\
\hline DF22 & 0 & 14 & 3.5 & 12.98 \\
\hline DF23 & 0 & 8.8 & 8.8 & 13.59 \\
\hline DF14 & 0 & 0 & 14 & 13.74 \\
\hline DF24 & 0 & 3.5 & 14 & 14.17 \\
\hline DF18 & 3.5 & 14 & 0 & 14.47 \\
\hline DF15 & 0 & 0 & 17.5 & 14.57 \\
\hline DF2 & 7 & 0 & 0 & 15.07 \\
\hline DF21 & 3.5 & 0 & 14 & 16.06 \\
\hline DF17 & 8.8 & 8.8 & 0 & 17.36 \\
\hline DF3 & 10.5 & 0 & 0 & 17.40 \\
\hline DF20 & 8.8 & 0 & 8.8 & 18.35 \\
\hline DF4 & 14 & 0 & 0 & 19.73 \\
\hline DF16 & 14 & 3.5 & 0 & 20.16 \\
\hline DF19 & 14 & 0 & 3.5 & 20.56 \\
\hline DF5 & 17.5 & 0 & 0 & 22.05 \\
\hline
\end{tabular}

2. The best performing single-salt formulations with respect to APLs were $2.9 \% \mathrm{NaCl}, 2.9 \% \mathrm{CaCl}_{2}, 3.6 \%$ $\mathrm{KCl}, 1.4 \% \mathrm{CaCl}_{2}, 0.7 \% \mathrm{CaCl}_{2}$ and $0.7 \% \mathrm{NaCl}$.

3. The best performing combination-salt formulation without $\mathrm{CaCl}_{2}$ was $\mathrm{KCl} 0.7 \%, \mathrm{NaCl} 2.9 \%$.

4. There was a significant difference between the Bingham plastic and power law models for the calculated pressure loss values. Values generated from the Bingham plastic model were generally two-eight times higher than those from the power law model.

5. The best performing fluids with respect to shale stability were the single-salt $\mathrm{KCl}$ fluids, in particular, the $3.6 \%$ formulation.

6. It appears that the higher the single-salt concentration of either $\mathrm{KCl}$ or $\mathrm{NaCl}$, the fluid becomes more effective towards shale stabilization. No such relationship was identified for $\mathrm{CaCl}_{2}$.

7. Of the combination salts, the best performing with respect to shale stabilization was the $\mathrm{KCl}-\mathrm{NaCl}$ fluids. The best was $\mathrm{KCl} 0.7 \%$ and $\mathrm{NaCl} 2.9 \%$.

8. Generally, with respect to shale stability, the formulations containing $\mathrm{CaCl}_{2}$ did not perform as well as the other fluids.

9. When taking into account both pressure loss and shale stability analyses, the best performing formulations are as follows as summarized in Table 6:
(a) $2.9 \% \mathrm{KCl}, 0.7 \% \mathrm{CaCl}_{2}$ (DF19);
(b) $3.6 \% \mathrm{KCl}$ (DF5);
(c) $0.7 \% \mathrm{KCl}, 2.9 \% \mathrm{NaCl}$ (DF18);
(d) $0.7 \% \mathrm{NaCl}$ (DF6);
(e) $2.9 \% \mathrm{CaCl}_{2}$ (DF14). 
Table 6 Summary of results regarding top five best performing formulations

\begin{tabular}{|c|c|c|c|c|c|c|c|c|c|c|}
\hline \multirow[t]{3}{*}{ Rank } & \multirow[t]{3}{*}{ Formulation \# } & \multirow[t]{3}{*}{ Composition } & \multirow{2}{*}{\multicolumn{3}{|c|}{$\begin{array}{l}\text { APL (psi/ft) (average } \\
\text { BP and PL) } \\
\text { Configurations }\end{array}$}} & \multicolumn{3}{|c|}{$\begin{array}{l}\text { DPPL (psi/ft) (aver- } \\
\text { age BP and PL) }\end{array}$} & \multirow{3}{*}{$\begin{array}{l}\text { Stability tests (solu- } \\
\text { tions) (avg \% loss by } \\
\text { mass) }\end{array}$} & \multirow[t]{3}{*}{$\begin{array}{l}\text { Stability tests (fluids) } \\
\text { (avg \% loss by mass) }\end{array}$} \\
\hline & & & & & & & & & & \\
\hline & & & 1 & 2 & 3 & 1 & 2 & 3 & & \\
\hline 1 & DF19 & $\mathrm{KCl} 2.9 \% / \mathrm{CaCl}_{2} 0.7 \%$ & 0.012 & 0.064 & 0.207 & 0.062 & 0.017 & 0.070 & 23 & 22 \\
\hline 2 & DF5 & $\mathrm{KCl} 3.6 \%$ & 0.015 & 0.067 & 0.216 & 0.104 & 0.031 & 0.084 & 10 & 14 \\
\hline 3 & DF18 & $\mathrm{KCl} 0.7 \% / \mathrm{NaCl} 2.9 \%$ & 0.013 & 0.070 & 0.226 & 0.098 & 0.029 & 0.081 & 13 & 25 \\
\hline 4 & DF6 & $\mathrm{NaCl} 0.7 \%$ & 0.013 & 0.069 & 0.219 & 0.106 & 0.032 & 0.084 & 20 & 25 \\
\hline 5 & DF14 & $\mathrm{CaCl}_{2} 2.9 \%$ & 0.014 & 0.064 & 0.205 & 0.110 & 0.034 & 0.084 & 23 & 25 \\
\hline
\end{tabular}

The information presented serves only to illustrate comparatively the results of the best formulations and does not account for cost

The pressure loss results shown are the calculated averages of the Bingham plastic and power law models

The pressure loss results shown are only for laminar flow at $150 \mathrm{gpm}$

10. The least expensive formulation was the $0.7 \% \mathrm{NaCl}$ formulation. The next least expensive formulations were $2.9 \% \mathrm{CaCl}_{2}$ (DF14) and $0.7 \% \mathrm{KCl}, 2.9 \% \mathrm{NaCl}$ (DF18).

11. Taking into account all factors of lowest frictional pressure loss, highest shale stabilizing ability and lowest cost, overall, the best performing formulation was $0.7 \%$ by weight sodium chloride. If cost is not a factor, the best performing formulation was $2.9 \% \mathrm{KCl}, 0.7 \%$ $\mathrm{CaCl}_{2}$ (DF19).
Open Access This article is distributed under the terms of the Creative Commons Attribution 4.0 International License (http://creativeco mmons.org/licenses/by/4.0/), which permits unrestricted use, distribution, and reproduction in any medium, provided you give appropriate credit to the original author(s) and the source, provide a link to the Creative Commons license, and indicate if changes were made.

\section{Appendix A1}

See Table 7.

Table 7 Data and information generated from viscometer readings

\begin{tabular}{|c|c|c|c|c|c|c|c|c|c|c|c|c|}
\hline & \multirow[t]{3}{*}{ Salt 1} & \multirow[t]{3}{*}{ Conc $(\%)$} & \multirow[t]{3}{*}{ Salt 2} & \multirow{3}{*}{$\begin{array}{l}\gamma(\mathrm{sec}-1) \\
\text { Conc }(\%)\end{array}$} & 1021 & 510.7 & 340.5 & 170.2 & 10.21 & 5.107 & $10 \mathrm{~s}$ & $10 \mathrm{~m}$ \\
\hline & & & & & \multicolumn{6}{|c|}{ Rheometer readings (rpm) } & & \\
\hline & & & & & 600 & 300 & 200 & 100 & 6 & 3 & & \\
\hline \multirow{4}{*}{$\begin{array}{l}\text { Control (base fluid } \\
\text { only) DF0 }\end{array}$} & None & Nil & None & Nil & 94 & 59 & 46 & 31 & 8 & 6 & 7 & 12 \\
\hline & None & Nil & None & Nil & 87 & 55 & 43 & 29 & 7 & 6 & 6 & 12 \\
\hline & None & Nil & None & Nil & 92 & 56 & 43 & 29 & 7 & 5 & 6 & 11 \\
\hline & $\mathrm{KCl}$ & 1 & None & Nil & 77 & 44 & 33 & 22 & 5 & 4 & 5 & 5 \\
\hline \multirow[t]{3}{*}{ DF1 } & $\mathrm{KCl}$ & 1 & None & Nil & 72 & 41 & 32 & 22 & 5 & 4 & 4 & 6 \\
\hline & $\mathrm{KCl}$ & 1 & None & Nil & 72 & 41 & 32 & 21 & 5 & 4 & 4 & 6 \\
\hline & $\mathrm{KCl}$ & 2 & None & Nil & 61 & 34 & 26 & 17 & 4 & 3 & 4 & 4 \\
\hline \multirow[t]{3}{*}{ DF2 } & $\mathrm{KCl}$ & 2 & None & Nil & 61 & 34 & 28 & 17 & 4 & 3 & 4 & 4 \\
\hline & $\mathrm{KCl}$ & 2 & None & Nil & 70 & 39 & 30 & 20 & 5 & 4 & 4 & 5 \\
\hline & $\mathrm{KCl}$ & 3 & None & Nil & 57 & 31 & 24 & 15 & 3 & 3 & 4 & 4 \\
\hline \multirow[t]{4}{*}{ DF3 } & $\mathrm{KCl}$ & 3 & None & Nil & 55 & 32 & 25 & 17 & 4 & 3 & 4 & 4 \\
\hline & $\mathrm{KCl}$ & 3 & None & Nil & 61 & 35 & 27 & 18 & 5 & 4 & 4 & 6 \\
\hline & $\mathrm{KCl}$ & 4 & None & Nil & 59 & 33 & 24 & 16 & 4 & 4 & 4 & 7 \\
\hline & $\mathrm{KCl}$ & 4 & None & Nil & 57 & 32 & 25 & 16 & 4 & 3 & 4 & 6 \\
\hline \multirow[t]{2}{*}{ DF4 } & $\mathrm{KCl}$ & 4 & None & Nil & 63 & 36 & 28 & 18 & 5 & 3 & 4 & 5 \\
\hline & $\mathrm{KCl}$ & 5 & None & Nil & 58 & 33 & 25 & 17 & 4 & 4 & 4 & 8 \\
\hline \multirow[t]{3}{*}{ DF5 } & $\mathrm{KCl}$ & 5 & None & Nil & 57 & 32 & 24 & 15 & 4 & 3 & 4 & 6 \\
\hline & $\mathrm{KCl}$ & 5 & None & Nil & 60 & 33 & 25 & 16 & 4 & 3 & 4 & 7 \\
\hline & $\mathrm{NaCl}$ & 1 & None & Nil & 63 & 35 & 27 & 18 & 5 & 3 & 5 & 5 \\
\hline
\end{tabular}


Table 7 (continued)

\begin{tabular}{|c|c|c|c|c|c|c|c|c|c|c|c|c|}
\hline & \multirow[t]{3}{*}{ Salt 1} & \multirow[t]{3}{*}{ Conc $(\%)$} & \multirow[t]{3}{*}{ Salt 2} & \multirow{3}{*}{$\begin{array}{l}\gamma(\mathrm{sec}-1) \\
\text { Conc }(\%)\end{array}$} & 1021 & 510.7 & 340.5 & 170.2 & 10.21 & 5.107 & \multirow[t]{3}{*}{$10 \mathrm{~s}$} & \multirow[t]{3}{*}{$10 \mathrm{~m}$} \\
\hline & & & & & \multicolumn{6}{|c|}{ Rheometer readings (rpm) } & & \\
\hline & & & & & 600 & 300 & 200 & 100 & 6 & 3 & & \\
\hline \multirow[t]{4}{*}{ DF6 } & $\mathrm{NaCl}$ & 1 & None & Nil & 60 & 34 & 26 & 17 & 4 & 3 & 4 & 4 \\
\hline & $\mathrm{NaCl}$ & 1 & None & Nil & 61 & 34 & 27 & 18 & 4 & 3 & 4 & 5 \\
\hline & $\mathrm{NaCl}$ & 2 & None & Nil & 72 & 42 & 33 & 22 & 6 & 5 & 5 & 7 \\
\hline & $\mathrm{NaCl}$ & 2 & None & Nil & 72 & 42 & 33 & 22 & 6 & 5 & 5 & 7 \\
\hline \multirow[t]{2}{*}{ DF7 } & $\mathrm{NaCl}$ & 2 & None & Nil & 68 & 40 & 31 & 21 & 5 & 4 & 5 & 6 \\
\hline & $\mathrm{NaCl}$ & 3 & None & Nil & 71 & 42 & 33 & 23 & 6 & 5 & 6 & 7 \\
\hline \multirow[t]{3}{*}{ DF8 } & $\mathrm{NaCl}$ & 3 & None & Nil & 57 & 31 & 24 & 16 & 4 & 3 & 3 & 4 \\
\hline & $\mathrm{NaCl}$ & 3 & None & Nil & 54 & 29 & 22 & 14 & 3 & 2 & 3 & 4 \\
\hline & $\mathrm{NaCl}$ & 4 & None & Nil & 62 & 34 & 26 & 18 & 5 & 4 & 4 & 5 \\
\hline \multirow[t]{3}{*}{ DF9 } & $\mathrm{NaCl}$ & 4 & None & Nil & 62 & 34 & 28 & 19 & 5 & 4 & 4 & 5 \\
\hline & $\mathrm{NaCl}$ & 4 & None & Nil & 61 & 34 & 26 & 17 & 4 & 3 & 4 & 5 \\
\hline & $\mathrm{NaCl}$ & 5 & None & Nil & 69 & 39 & 30 & 20 & 5 & 4 & 4 & 6 \\
\hline \multirow[t]{4}{*}{ DF10 } & $\mathrm{NaCl}$ & 5 & None & Nil & 66 & 37 & 28 & 19 & 5 & 4 & 5 & 5 \\
\hline & $\mathrm{NaCl}$ & 5 & None & Nil & 68 & 38 & 29 & 19 & 5 & 3 & 4 & 5 \\
\hline & $\mathrm{CaCl}_{2}$ & 1 & None & Nil & 47 & 27 & 21 & 14 & 4 & 4 & 4 & 9 \\
\hline & $\mathrm{CaCl}_{2}$ & 1 & None & Nil & 50 & 27 & 23 & 13 & 4 & 3 & 4 & 9 \\
\hline \multirow[t]{3}{*}{ DF11 } & $\mathrm{CaCl}_{2}$ & 1 & None & Nil & 50 & 28 & 22 & 15 & 4 & 4 & 4 & 9 \\
\hline & $\mathrm{CaCl}_{2}$ & 2 & None & Nil & 55 & 31 & 25 & 17 & 6 & 5 & 7 & 16 \\
\hline & $\mathrm{CaCl}_{2}$ & 2 & None & Nil & 56 & 33 & 26 & 18 & 6 & 5 & 7 & 14 \\
\hline \multirow[t]{3}{*}{ DF12 } & $\mathrm{CaCl}_{2}$ & 2 & None & Nil & 51 & 31 & 24 & 17 & 6 & 5 & 7 & 14 \\
\hline & $\mathrm{CaCl}_{2}$ & 3 & None & Nil & 61 & 36 & 28 & 20 & 7 & 6 & 8 & 19 \\
\hline & $\mathrm{CaCl}_{2}$ & 3 & None & Nil & 53 & 30 & 23 & 16 & 5 & 5 & 6 & 16 \\
\hline \multirow[t]{3}{*}{ DF13 } & $\mathrm{CaCl}_{2}$ & 3 & None & Nil & 58 & 33 & 26 & 18 & 6 & 5 & 6 & 15 \\
\hline & $\mathrm{CaCl}_{2}$ & 4 & None & Nil & 52 & 30 & 23 & 16 & 5 & 4 & 6 & 12 \\
\hline & $\mathrm{CaCl}_{2}$ & 4 & None & Nil & 50 & 28 & 22 & 15 & 5 & 4 & 5 & 11 \\
\hline \multirow[t]{3}{*}{ DF14 } & $\mathrm{CaCl}_{2}$ & 4 & None & Nil & 62 & 36 & 29 & 20 & 7 & 6 & 9 & 25 \\
\hline & $\mathrm{CaCl}_{2}$ & 5 & None & Nil & 75 & 48 & 40 & 28 & 12 & 11 & 15 & 38 \\
\hline & $\mathrm{CaCl}_{2}$ & 5 & None & Nil & 78 & 51 & 42 & 29 & 12 & 11 & 15 & 40 \\
\hline \multirow[t]{2}{*}{ DF15 } & $\mathrm{CaCl}_{2}$ & 5 & None & Nil & 76 & 48 & 41 & 29 & 12 & 10 & 14 & 37 \\
\hline & $\mathrm{KCl}$ & 4 & $\mathrm{NaCl}$ & 1 & 70 & 39 & 30 & 20 & 5 & 4 & 5 & 8 \\
\hline DF16 & $\mathrm{KCl}$ & 4 & $\mathrm{NaCl}$ & 1 & 61 & 35 & 27 & 18 & 5 & 4 & 4 & 8 \\
\hline & $\mathrm{KCl}$ & 4 & $\mathrm{NaCl}$ & 1 & 62 & 33 & 27 & 17 & 4 & 3 & 3 & 4 \\
\hline & $\mathrm{KCl}$ & 2.5 & $\mathrm{NaCl}$ & 2.5 & 65 & 37 & 29 & 19 & 5 & 4 & 4 & 6 \\
\hline DF17 & $\mathrm{KCl}$ & 2.5 & $\mathrm{NaCl}$ & 2.5 & 65 & 37 & 29 & 19 & 5 & 4 & 4 & 6 \\
\hline & $\mathrm{KCl}$ & 2.5 & $\mathrm{NaCl}$ & 2.5 & 66 & 37 & 29 & 18 & 5 & 4 & 4 & 6 \\
\hline & $\mathrm{KCl}$ & 1 & $\mathrm{NaCl}$ & 4 & 64 & 35 & 27 & 17 & 4 & 3 & 4 & 4 \\
\hline DF18 & $\mathrm{KCl}$ & 1 & $\mathrm{NaCl}$ & 4 & 63 & 34 & 26 & 17 & 4 & 3 & 4 & 4 \\
\hline & $\mathrm{KCl}$ & 1 & $\mathrm{NaCl}$ & 4 & 64 & 36 & 27 & 18 & 4 & 4 & 4 & 4 \\
\hline & $\mathrm{KCl}$ & 4 & $\mathrm{CaCl}_{2}$ & 1 & 53 & 28 & 22 & 14 & 4 & 3 & 3 & 4 \\
\hline & $\mathrm{KCl}$ & 4 & $\mathrm{CaCl}_{2}$ & 1 & 53 & 28 & 23 & 14 & 3 & 3 & 3 & 4 \\
\hline DF19 & $\mathrm{KCl}$ & 4 & $\mathrm{CaCl}_{2}$ & 1 & 52 & 27 & 22 & 14 & 4 & 3 & 4 & 4 \\
\hline & $\mathrm{KCl}$ & 2.5 & $\mathrm{CaCl}_{2}$ & 2.5 & 49 & 27 & 20 & 13 & 4 & 3 & 3 & 7 \\
\hline & $\mathrm{KCl}$ & 2.5 & $\mathrm{CaCl}_{2}$ & 2.5 & 50 & 28 & 21 & 14 & 4 & 3 & 4 & 7 \\
\hline DF20 & $\mathrm{KCl}$ & 2.5 & $\mathrm{CaCl}_{2}$ & 2.5 & 51 & 28 & 22 & 14 & 4 & 3 & 4 & 9 \\
\hline & $\mathrm{KCl}$ & 1 & $\mathrm{CaCl}_{2}$ & 4 & 74 & 47 & 39 & 27 & 10 & 9 & 13 & 35 \\
\hline & $\mathrm{KCl}$ & 1 & $\mathrm{CaCl}_{2}$ & 4 & 77 & 49 & 41 & 29 & 11 & 10 & 15 & 31 \\
\hline DF21 & $\mathrm{KCl}$ & 1 & $\mathrm{CaCl}_{2}$ & 4 & 77 & 49 & 41 & 28 & 11 & 10 & 14 & 35 \\
\hline & $\mathrm{NaCl}$ & 4 & $\mathrm{CaCl}_{2}$ & 1 & 62 & 34 & 27 & 18 & 4 & 3 & 4 & 5 \\
\hline
\end{tabular}


Table 7 (continued)

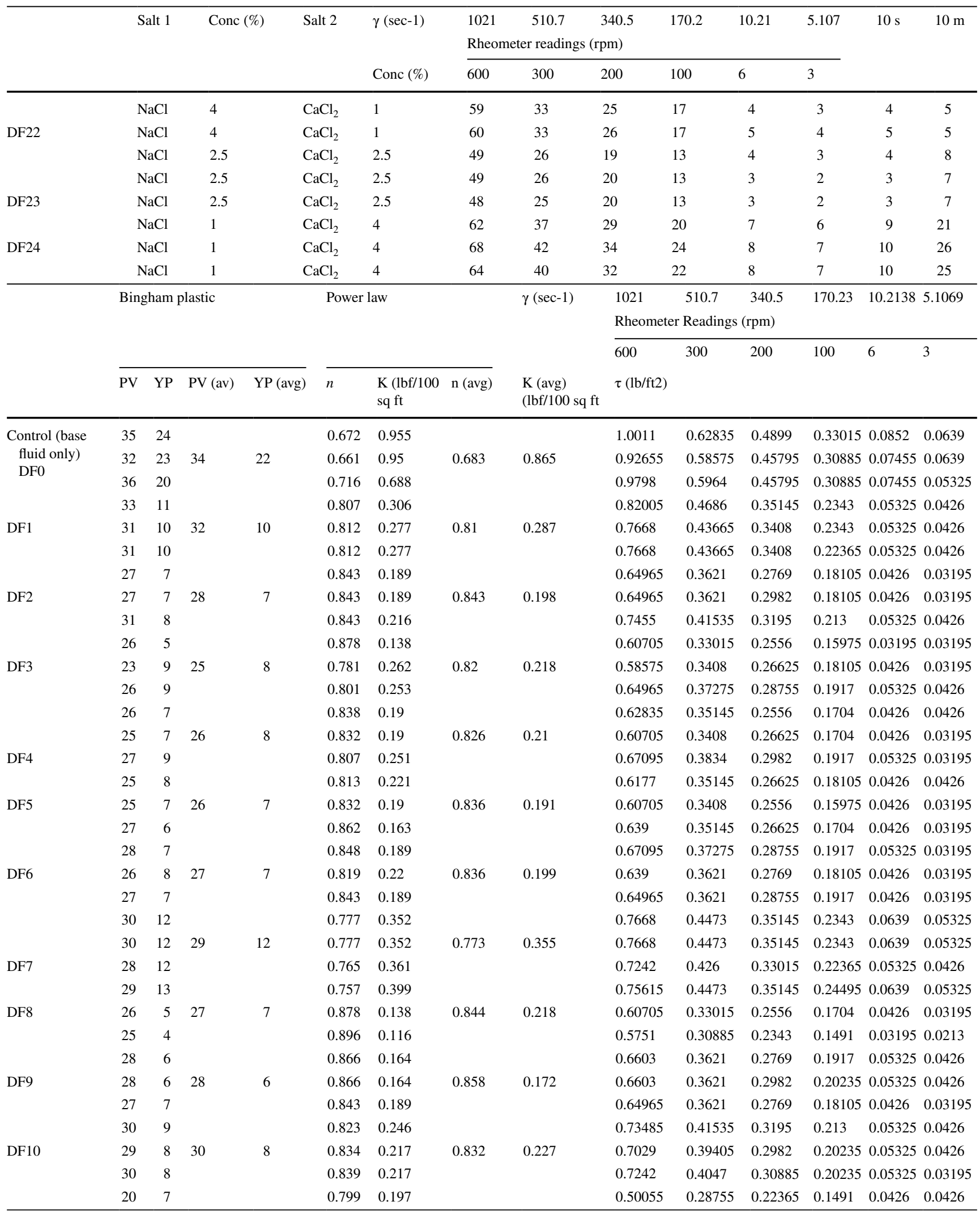


Table 7 (continued)

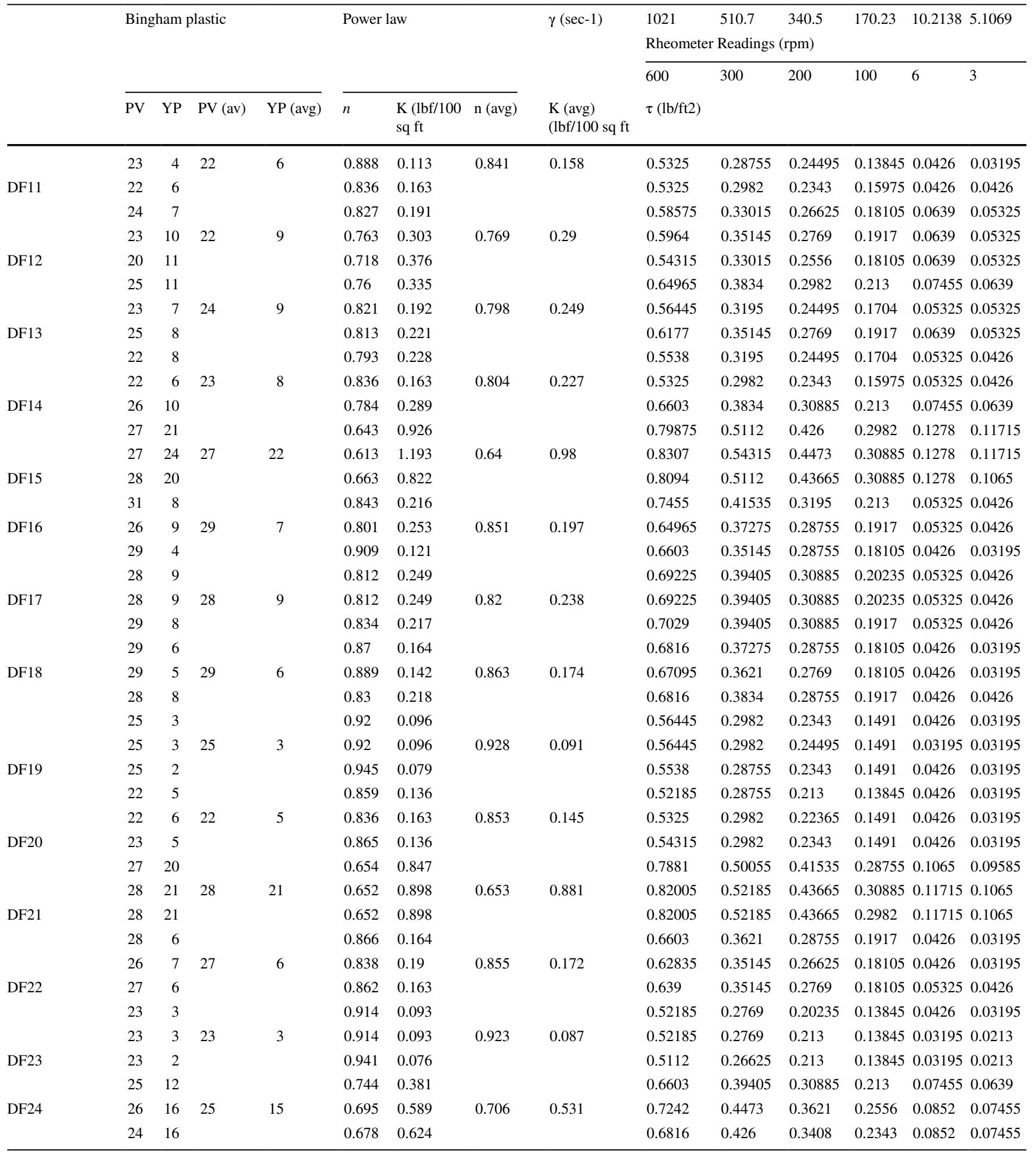




\section{Appendix A2}

See Fig. 8.
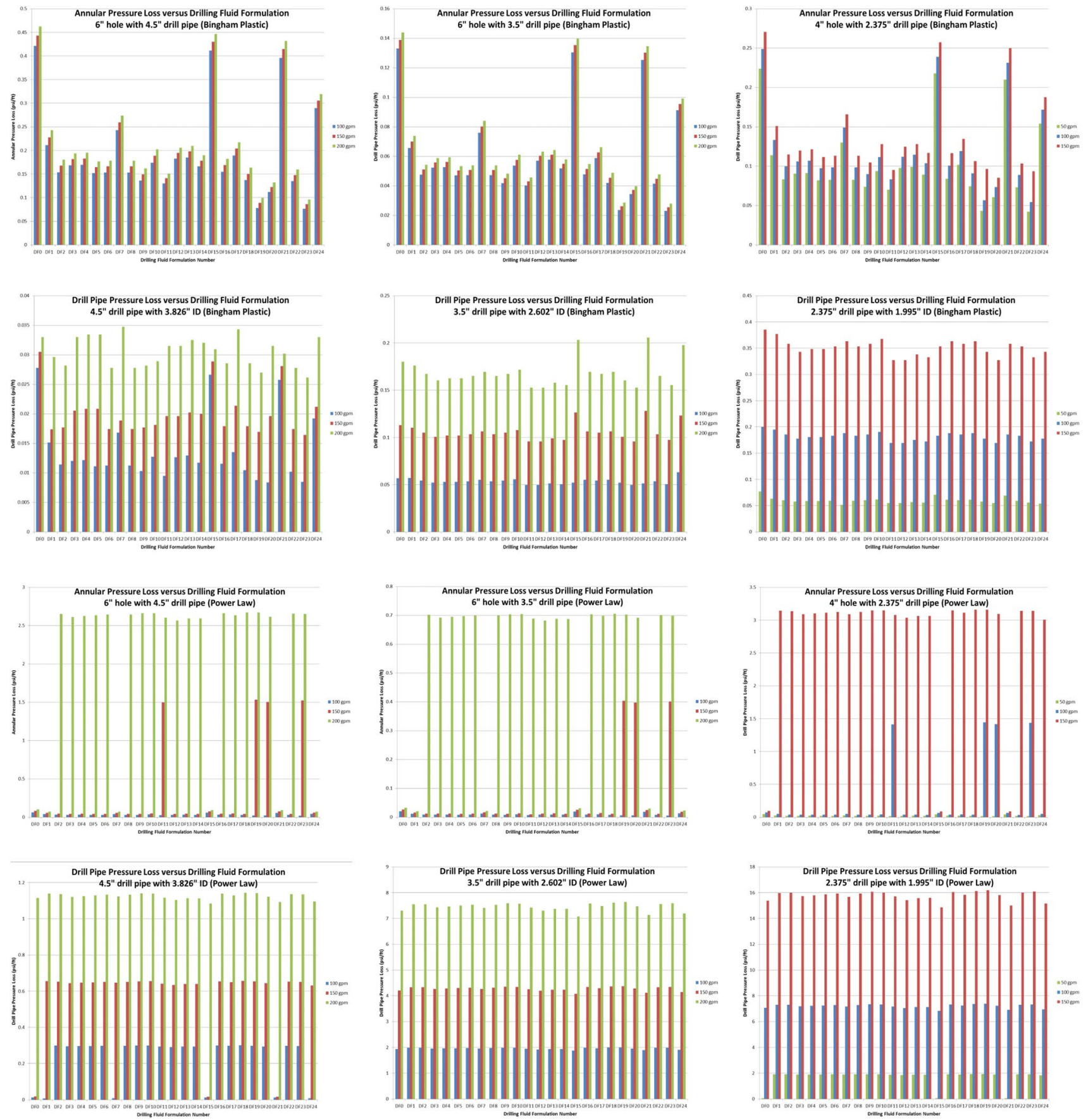

Fig. 8 Calculated annular pressure losses (laminar and turbulent flow included) 


\section{Appendix A3}

See Fig. 9.
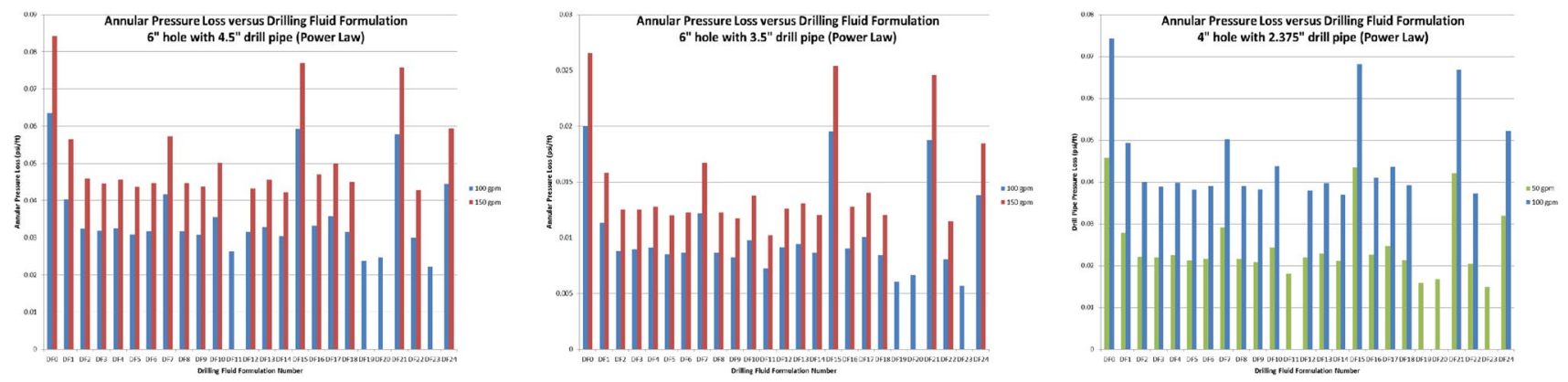

Fig. 9 Calculated annular pressure losses (turbulent flow excluded)

\section{References}

Bingham EC (1922) Fluidity and plasticity. McGraw Hill Book Company Inc, New York

Bode DJ, Noffke RB, Nickens HV (1991) Well-control methods and practices in small diameter wellbores. J Pet Technol Soc Pet Eng. https://doi.org/10.2118/19526-PA

Cartalos U, Dupuis D (1993) An analysis accounting for the combined effect of drill string rotation and eccentricity on pressure losses in slimhole drilling. Soc Pet Eng. https://doi.org/10.2118/25769-MS

Delwiche RA, Lejeune MWD, Mawet PFBN, Roland V (1992) Slim hole drilling hydraulics. Soc Pet Eng. https://doi. org/10.2118/24596-MS

Energy-pedia N (2012) Trinidad: range resources updates drilling operations on its Morne Diablo Block. http://www.energy-pedia .com/news/trinidad/new-151503. Accessed 20 Aug 2014

Enilari MG (2005) Development and evaluation of various drilling fluids for slim hole wells. M.Sc. thesis, University of Oklahoma, Graduate College

Fanning JT (1877) A practical treatise on water-supply engineering. Van Nostrand, New York

Finger J, Jacobson R (1999) Slim hole drilling, logging, and completion technology — an update. Geothermal Research Department, Sandia National Laboratories, Albuquerque

Friedheim J, Guo Q, Young S, Gomez S (2011) Testing and evaluation techniques for drilling fluids-shale interaction and shale stability. American Rock Mechanics Association, Alexandria

Herschel WH, Bulkley R (1926) Konsistenzmessungen von GummiBenzollösungen. Kolloid Zeitschrift 39:291-300. https://doi. org/10.1007/BF01432034

Jahn F, Cook M, Graham M (2008) Hydrocarbon exploration and production, 2nd edn. Elsevier, Amsterdam

Kendall HA, Goins WC Jr (1960) Design and operation of jet-bit program for maximum hydraulic horsepower, impact force and jet velocity. Pet Trans AIME 219(99):238-250
Lal M (1999) Shale stability: drilling fluid interaction and shale strength. Soc Pet Eng. https://doi.org/10.2118/54356-MS

Newton I (1687) Philosophiae Naturalis Principia Mathematica. Translated by Andrew Motte. Daniel Adee, New York

Ostwald (1929) de-Waele-Ostwald equation. Kolloid Zeitschrift 47(2) $176-187$

Ramkhalawan CD, Khan J, Bainey KR (1995) Thirty (30) years of steamflooding: reservoir management and operational experiences. In: Proceedings of the SPE annual technical conference and exhibition, October 22-25, SPE 30772-MS, Dallas, Texas

Reynolds O (1883) An experimental investigation of the circumstances which determine whether the motion of water shall be direct or sinuous, and of the law of resistance in parallel channels. Philos Trans R Soc 174(0):935-982. https://doi.org/10.1098/ rstl.1883.0029 (JSTOR 109431)

Ross BR, Faure AM, Kitsios EE, Oosterling P, Zettle RS (1992) Innovative slim hole completions. Soc Pet Eng. https://doi. org/10.2118/24981-MS

Shanks FE II, Williams KR (1993) Slim hole exploration requires proper technical preparation. Soc Pet Eng. https://doi. org/10.2118/26337-MS

Thonhauser G, Millheim KK, Spoerker HF (1995) The applicability of current slimhole hydraulics algorithms under field conditions-a critical review. Soc Pet Eng. https://doi.org/10.2118/30489-MS

Wach GD, Archie C (2008) Regional distribution and controls of heavy oil and oil sand in the Eastern Venezuelan and Trinidad Basins. AAPG databases/search and discovery. Article \#40285. http:// www.searchanddiscovery.net/documents/2008/08022wac h02/ images/wach.pdf. Accessed Sept 2015

Zhu T, Carroll HB (1994) Status report, a review of slim hole drilling. National Institute for Petroleum and Energy Research and BDM Oklahoma, Bartlesville

Publisher's Note Springer Nature remains neutral with regard to jurisdictional claims in published maps and institutional affiliations. 